Decy Wulan S., Ni Nyoman Yuliati, E Rusli Amrul : Pengaruh Pengendalian Internal.....

\title{
PENGARUH PENGENDALIAN INTERNAL DAN INTEGRITAS PADA KECENDERUNGAN KECURANGAN AKUNTANSI (Studi Kasus Pada Dinas SKPD Kota Mataram)
}

\author{
Decy Wulan Singgih \\ Ni Nyoman Yuliati \\ Rusli Amrul \\ Sekolah Tinggi Ilmu Ekonomi AMM Mataram
}

\begin{abstract}
This study aims to determine the Influence of Internal Control And Integrity On Fraud Accounting Trend (Case Study On SKPD Office of Mataram City). This type of research includes associative research. The population used is the employees who are on the SKPD Office of Mataram City, while the number of samples taken are as many as 60 employees who are at the Office SKPD Mataram using purposive sampling techniques. Data collected are primary data in the form of questionnaire. The data has been collected and then analyzed using multiple linear regression analysis, by utilizing SPSS for Windows application program. The result of data processing shows that the internal control and integrity variables have a negative and significant effect on accounting fraud. Next for internal control and integrity variable simultaneously have significant effect on the tendency of accounting fraud in office SKPD Kota Mataram.
\end{abstract}

Keywords: Internal Control, Integrity, Accounting Fraud.

\section{Latar Belakang Masalah}

\section{PENDAHULUAN}

Kecurangan terjadi karena adanya tekanan, peluang dan rasionalisasi, dimana seseorang mungkin merasa mendapat tekanan untuk melakukan kecurangan karena adanya kebutuhan atau masalah finansial. Kesempatan melakukan kecurangan biasanya dipicu karena adanya peluang yang menyebabkan pelaku secara leluasa menjalankan aksinya yang disebabkan oleh pengendalian internal yang lemah dan ketidak displinan. Kecurangan menggambarkan setiap upaya penipuan yang disengaja, yang dimkasudkan untuk mengambil harta atau hak orang atau pihak lain (Arens, 2008:430).

Pengendalian internal adalah suatu proses yang dijalankan oleh dewan komisaris, manajemen dan personalia entitas lain yang didisain untuk memberikan keyakinan memadai tentang pencapain tiga golongan 
seperti keandalan pelaporan keuangan, efektifitas dan efesiensi operasi, dan kepatuhan terhadap hukum dan peraturan yang berlaku. Jika pengendalian internal suatu perusahaan lemah maka kemungkinan terjadinya kesalahan dan kecurangan semakin besar. Sebaliknya, jika pengendalian internalnya kuat, maka kemungkinan terjadinya kecurangan dapat diperkecil (Tunggal, 2010:195).

Selain pengendalian internal juga terdapat integritas pegawai yang bisa menekan terjadinya tingkat kecurangan, integritas adalah suatu komitmen pribadi yang teguh terhadap prinsip ideologi yang etis dan menjadi bagian dari konsep diri yang ditampilkan melalui perilakunya (Schlenker, 2008). Mulyadi (2002) menyatakan integritas sebagai prinsip moral yang tidak memihak dan jujur, seseorang yang berintegritas tinggi memandang fakta seperti apa adanya dan mengemukakan fakta tersebut seperti apa adanya.

Terdapat beberapa penelitian terdahulu yang membahas mengenai pengendalian internal, integritas dan kecuranagn yang terjadi, diantaranya Tiro (2014) melakukan penelitian tentang Pengaruh Pengendalian Internal Terhadap Kecenderungan Kecurangan (Fraud) pada Pemerintah Kota Palopo. Hasil penelitian ini menunjukkan bahwa pengendalian internal secara parsial berpengaruh positif. Sedangkan dalam penelitian Dewi (2016) yang berjudul Pengaruh Pengendalian Internal dan Integritas pada Kecenderungan Kecurangan Akuntansi (Studi pada SKPD Kota Denpasar), hasil analisis data menunjukkan bahwa pengendalian internal dan integritas berpengaruh negatif pada kecurangan akuntansi.

Dengan pertimbangan tersebut dan banyaknya kasus kecurangan akuntansi yang terjadi di sektor pemerintahan, maka penting dilakukan penelitian kecurangan akuntasi untuk mengetahui faktor apa yang mempengaruhi terjadinya kecurangan akuntansi. Meski kecurangan akuntansi ini diduga sudah menahun, namun belum terdapat kajian teoritis dan empiris secara komprehensif, oleh karena itu fenomena ini dianggap perlu dikaji.

Sesuai dengan latar belakang yang telah dikemukakan, maka dengan ini penulis melakukan sebuah penelitian yang berjudul "Pengaruh Pengendalian Internal dan Integritas pada Kecenderungan Kecurangan Akuntansi (Studi Kasus pada Dinas SKPD Kota Mataram)". Rumusan Masalah

Dari latar belakang diatas, maka dapat dirumuskan permasalahan sebagai berikut: 
Decy Wulan S., Ni Nyoman Yuliati, \& Rusli Amrul : Pengaruh Pengendalian Internal.....

1) Apakah pengendalian internal berpengaruh pada kecenderungan kecurangan akuntansi di Dinas SKPD Kota Mataram?

2) Apakah integritas berpengaruh pada kecenderungan kecurangan akuntansi di Dinas SKPD Kota Mataram?

3) Apakah pengendalian internal dan integritas berpengaruh secara simultan terhadap kecenderungan kecurangan akuntansi di Dinas SKPD Kota Mataram?

\section{Tujuan Penelitian}

1) Untuk mengetahui pengaruh pengendalian internal pada kecenderungan kecurangan akuntansi di Dinas SKPD Kota Mataram.

2) Untuk mengetahui pengaruh integritas pada kecenderungan kecurangan akuntansi di Dinas SKPD Kota Mataram.

3) Untuk mengetahui pengaruh pengendalian internal dan integritas secara simultan terhadap kecenderungan kecurangan akuntansi di Dinas SKPD Kota Mataram.

\section{Manfaat penelitian}

Dalam aplikasi, praktik dapat memberikan pemahaman yang lebih baik bagi pihak-pihak yang berkepentingan bagi lingkungan kerja pemerintahan terhadap pengendalian internal dan integritas terhadap kasus kecenderungan kecurangan akuntansi.

\section{TINJAUAN TEORITIS}

Beberapa tinjauan yang dapat digunakan sebagai acuan untuk melanjutkan penelitian menurut beberapa ahli yaitu:

\section{Pengertian Pengendalian Internal}

Menurut Mulyadi (2010:163) Pengendalian Internal adalah:

"sistem pengendalian internal meliputi struktur organisasi, metode dan ukuran-ukuran yang dikoordinasikan untuk menjaga kekayaan organisasi, mengecek ketelitian dan keandalan data akuntansi, mendorong efisiensi dan mendorong dipatuhinya kebijakan manajemen".

Sedangkan dalam buku Ikatan Akuntan Indonesia (IAI) seperti dinyatakan dalam PSA Nomor 69 (IAI, 2001:319) :

"Suatu proses yang dijalankan oleh dewan komisaris, manajemen, dan personil lain entitas yang didesain untuk memberikan keyakinakn memadai tentang pencapaian tiga golongan tujuan seperti keandalan pelaporan keuangan, efektivitas dan efisiensi operasi, dan kepatuhan 
terhadap hukum dan peraturan yang berlaku'.

Secara umum Peraturan Pemerintah (PP) Nomor 60 Tahun 2008 tentang Sistem Pengendalian Internal Pemerintah (SPIP). Menurut PP Nomor 60 Tahun 2008 pasal 1 ayat 1 sistem pengendalian internal adalah:

"Suatu proses sistematik untuk memperoleh dan mengevaluasi bukti secara objektif mengenai pernyataan-pernyataan tentang kegiatan dan kejadian ekonomi, dengan tujuan tertentu untuk menetapkan tingkat kesesuaian antara pernyataan-pernyataan tersebut dengan kriteria yang telah ditetapkan, serta penyampaian hasil-hasilnya kepada pemakai yang berkepentingan".

\section{Integritas}

Menurut Kamus Besar Bahasa Indonesia, pengertian integritas adalah mutu, sifat, dan keadaan yang menggambarkan kesatuan yang utuh, sehingga memiliki potensi dan kemampuan memancarkan kewibawaan dan kejujuran. Mulyadi (2002) mendefinisikan integritas sebagai prinsip moral yang tidak memihak, jujur, seseorang yang berintegritas tinggi memandang fakta seperti apa adanya dan mengemukakan fakta tersebut seperti apa adanya.

\section{Kecurangan Akuntansi}

Kecurangan akuntansi merupakan penyalahgunaan/penggelapan atau perbuatan yang tidak semestinya. Kecurangan secara singkat dinyatakan sebagai suatu penyajian yang palsu atau penyembunyian fakta yang material yang menyebabkan seseorang memiliki sesuatu. Kecurangan mencakup kejutan, tipu daya, cara-cara licik dan tidak jujur yang digunakan untuk menipu orang lain (Tunggal, 1992:17).

Dalam buku Ikatan Akuntan Indonesia (IAI) menjelaskan kecurangan akuntansi sebagai berikut:

1) Salah saji yang timbul dari kecurangan dalam pelaporan keuangan yaitu salah saji atau penghilangan secara sengaja jumlah atau pengungkapan dalam laporan keuangan untuk mengelabui pemakai laporan keuangan.

2) Salah saji yang timbul dari perlakuan tidak semestinya terhadap aktiva (seringkali disebut dengan penyalahgunaan atau penggelapan) yang berkaitan dengan pencurian aktiva entitas yang berakibat laporan keuangan tidak disajikan sesuai dengan Prinsip Akuntansi yang Berlaku Umum (PABU) di Indonesia. 
Decy Wulan S., Ni Nyoman Yuliati, \& Rusli Amrul : Pengaruh Pengendalian Internal.....

\section{Tipe-Tipe Kecurangan Akuntansi}

Menurut Tunggal (2013) terdapat dua tipe kecurangan akuntansi yaitu:

1. Kecurangan eksternal

Kecurangan yang dilakukan oleh pihak luar terhadap suatu perusahaan/entitas, seperti kecurangan yang dilakukan pelanggan terhadap usaha, wajib pajak terhadap pemerintah.

2. Kecurangan internal

Tindakan tidak legal yang dilakukan oleh karyawan, manajer dan eksekutif terhadap perusahaan tempat mereka bekerja. Kecurangan tersebut akan menimbulkan kerugian yang besar bagi perusahaan itu sendiri.

\section{Klasifikasi Fraud}

The Association of Certified Fraud Examiners (ACFE)atau Asosiasi Pemeriksa Kecurangan Bersertifikat dalam Zulkarnain (2013), mengklasifikasikan fraud (kecurangan) dalam beberapa klasifikasi, dan dikenal dengan istilah Fraud Tree yaitu:

1) Kecurangan Laporan Keuangan (Financial Statement Fraud)

Kecurangan laporan keuangan dapat didefinisikan sebagai kecurangan yang dilakukan oleh manajemen dalam bentuk salah saji material laporan keuangan yang merugikan investor dan kreditor. Kecurangan ini dapat bersifat finansial atau kecurangan non-finansial.

2) Penyalahgunaan Aset (Asset Misappropriation)

Penyalahgunaan aset dapat digolongkan ke dalam kecurangan kas dan kecurangan atas persediaan dan aset lainnya, serta pengeluaran-pengeluaran biaya secara curang (fraudulent disbursement).

3) Korupsi (Corruption)

Korupsi dalam konteks pembahasan ini adalah korupsi menurut ACFE, bukannya pengertian korupsi menurut UU Pemberantasan TPK di Indonesia. Menurut ACFE, korupsi terbagi ke dalam pertentangan kepentingan (conflict of interest), suap (bribery), pemberian ilegal (illegal gratuity), dan pemerasan (economic extortion).

\section{Fraud Pada Sector Pemerintahan}

The Association of Certified Fraud Examiners (ACFE)atau Asosiasi Pemeriksa Kecurangan Bersertifikat dalam Zulkarnain (2013) mengatakan semua jenis fraud dapat terjadi pada sektor pemerintahan, akan tetapi yang paling sering terjadi adalah korupsi. Korupsi adalah tindakan seorang pejabat atau petugas yang secara tidak sah dan tidak dapat dibenarkan memanfaatkan pekerjaannya atau karakternya untuk mendapatkan keuntungan bagi dirinya sendiri atau untuk orang lain dengan melanggar 
kewajiban dan hak. Korupsi meliputi penyuapan, konflik kepentingan, pemberian tanda terima kasih yang tidak sah, dan pemerasan secara ekonomi.

\section{Kerangka Berpikir Penelitian}

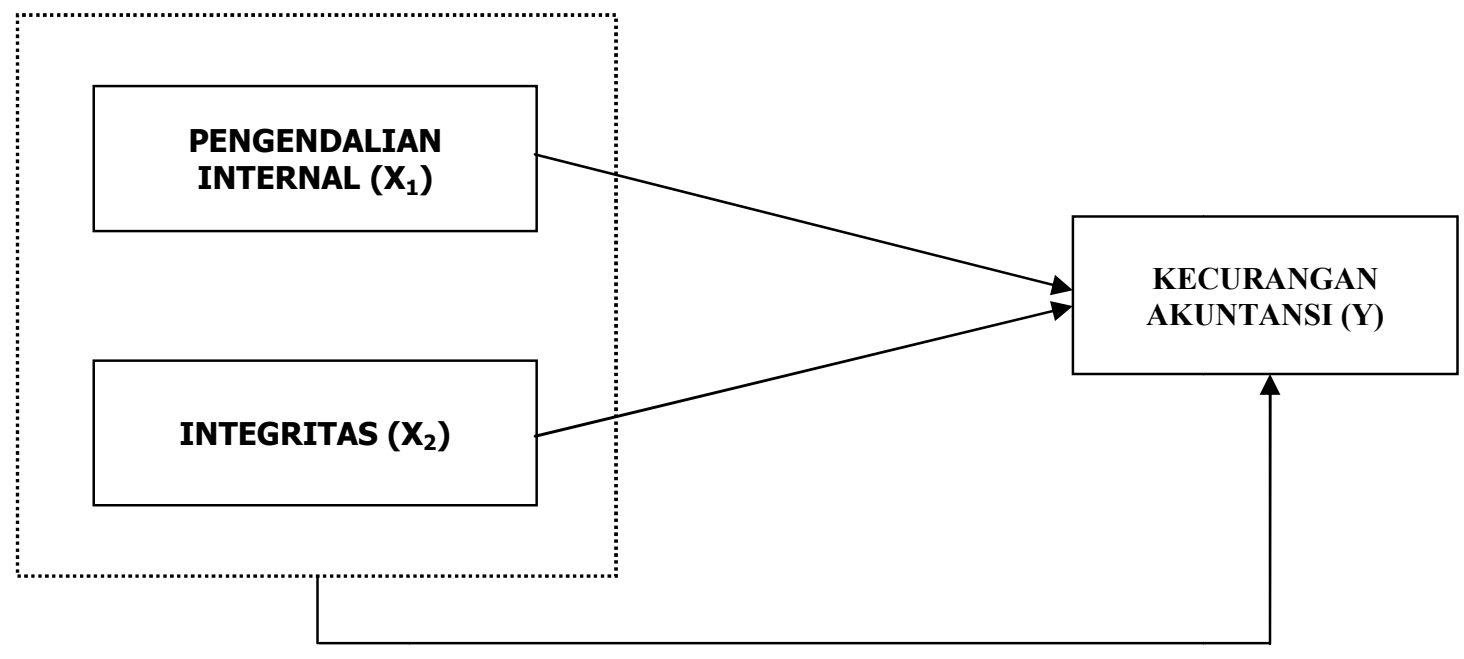

\section{Hipotesis}

Hipotes merupakan dugaan sementara, sehingga banyak yang dapat dijadikan pedoman terutama adalah hasil penelitian sebelumnya. Maka hipotesis dalam penelitian ini dinyatakan sebagai berikut :

1. Pengendalian Internal berpengaruh pada Kecenderungan Kecurangan Akuntansi

2. Integritas berpengaruh pada Kecenderungan Kecurangan Akuntansi

3.Pengendalian Internal dan Integritas berpengaruh secara simultan pada Kecenderungan Kecurangan Akuntansi

\section{METODE PENELITIAN}

\section{Jenis Penelitian}

Jenis penelitian yang digunakan adalah asosiatif. Penelitian asosiatif merupakan penelitian yang bertujuan untuk mengetahui hubungan antara dua variabel atau lebih.

\section{Populasi dan Sampel}

Populasi

Populasi adalah wilayah generalisasi yang terdiri atas obyek/subyek yang mempunyai kualitas dan karakteristik tertentu yang ditetapkan oleh peneliti untuk dipelajari dan kemudian ditarik kesimpulannya (Sugiyono, 
Decy Wulan S., Ni Nyoman Yuliati, \& Rusli Amrul : Pengaruh Pengendalian Internal.....

2009:80). Dalam penelitian ini terdapat 12 Dinas SKPD di Kota Mataram yang akan dijadikan sebagai populasi, dimana masing-masing Dinas SKPD terdapat 10 orang pegawai yang bekerja dibagian keuangan.

\section{Sampel Penelitian}

Sampel adalah bagian dari jumlah karakteristik yang dimiliki oleh populasi tersebut (Sugiyono, 2009:81). Teknik pengambilan sampel yang digunakan dalam penelitian ini adalah purposive sampling yaitu pengambilan sampel terhadap populasi yang memiliki kriteria tertentu. Sampel yang akan diambil dalam penelitian ini adalah sebanyak 5 orang pegawai yang bekerja dibagian keuangan setiap Dinas Satuan Kerja Perangkat Daerah (SKPD) Pemerintahan Kota Mataram yang berjumlah 60 orang dan kriteria yang digunakan dalam pemilihan sampel adalah sebagai berikut:

Tabel 1. Kriteria Sampel

\begin{tabular}{|l|l|}
\hline No & Kriteria \\
\hline 1 & Pejabat yang mengelola keuangan dan pengambil keputusan. \\
\hline 2 & Pejabat pembuat komitmen. \\
\hline 3 & Bendahara yang bekerja pada bagian keuangan. \\
\hline
\end{tabular}

\section{Teknik Pengumpulan Data}

Teknik pengumpulan data yang digunakan dalam penelitian ini yaitu dengan menggunakan kuesioner untuk mendapatkan data primer. Kuesioner adalah daftar pertanyaan terstruktur yang diajukan pada responden. Kuesioner diberikan kepada pejabat yang mengelola keuangan dan pejabat pengambil keputusan, pejabat pembuat komitmen dan bendaharayang bekerja pada bagian keuangan yang terpilih sebagai sampel pada Satuan Kerja Perangkat Daerah (SKPD) Pemerintah Kota Mataram.

\section{Pengujian Kualitas Data Uji Validitas}

Uji validitas digunakan untuk mengukur sah/valid atau tidaknya suatu kuesioner sebagai suatu instrumen penelitian. Kuesioner dikatakan valid jika pertanyaan dalam kuesioner mampu mengungkapkan sesuatu yang akan diukur oleh kuesioner tersebut (Sunyoto, 2011:72).

Pengujian dilakukan dengan menggunakan metode korelasi Product Moment Pearson yang kemudian dibandingkan dengan $r$ tabel. Apabila nilai korelasinya lebih besar dari $r$ tabel, maka pernyataan tersebut dianggap konsisten secara internal. Jika nilai korelasinya lebih kecil dari nilai $r$ tabel, maka pernyataan dianggap tidak valid dan harus dikeluarkan dari pengujian. 


\section{Uji Reliabilitas}

Reliabilitas adalah alat untuk mengukur suatu kuesioner yang merupakan indikator dari variabel yang diteliti (Sunyoto, 2011:67). Pertanyaan dalam kuesioner dikatakan handal jika jawaban seseorang terhadap pertanyaan adalah konsisten.

Uji reliabilitas pengukuran dalam penelitian ini dilakukan dengan menggunakan Cronbach 's alpha. Koefisien Cronbach's alpha yang lebih dari 0,6 disebut reliabel. Hal ini menunjukkan keandalan instrumen. Selain itu, Cronbach's alpha yang semakin mendekati 1 menunjukkan semakin tinggi reliabilitasnya.

\section{Uji Normalitas}

Uji asumsi ini akan menguji data variabel bebas $(X)$ dan data variabel terikat $(Y)$ pada persamaan regresi yang dihasilkan, apakah berdistribusi normal atau berdistribusi tidak normal (Sunyoto, 2011:84). Uji ini bertujuan untuk menguji apakah ada variabel pengganggu atau variabel residual dalam model regresi.

Uji normalitas data pada penelitian ini dilakukan dengan menggunakan analisis grafik. Pengambilan keputusan dengan analisis grafik dapat dilakukan dengan dua cara yaitu melalui grafik histogram dan normal probability plot. Untuk grafik histogram, jika data rill membentuk garis kurva cenderung tidak simetri terhadap mean (U) maka dapat dikatakan data berdistribusi tidak normal, begitupun sebaliknya. Sementara untuk cara normal probability plot, dikatakan berdistribusi normal jika garis data rill mengikuti garis diagonal dan cara ini dianggap lebih handal daripada grafik histogram karena cara ini membandingkan data rill dengan data distribusi normal (Sunyoto, 2011:89)

\section{Uji Multikolinieritas}

Uji asumsi klasik ini digunakan untuk analisis regresi berganda yang terdiri dari minimal dua variabel bebas, dimana akan diukur tingkat asosiasi (keeratan) hubungan atau pengaruh antarvariabel bebas tersebut melalui besaran koefisien korelasi $(r)$. Dalam menentukan terjadinya multikolinieritas dapat digunakan cara sebagai berikut:

a) Jika koefisien korelasi antravariabel bebas lebih besar dari 0,6.

b) Nilai tolerance adalah besarnya tingkat kesalahan yang dibenarkan secara statistik (a).

c) Nilai variance inflation factor (VIF) adalah faktor inflasi penyimpangan baku kuadrat.

Dapat disimpulkan bahwa, jika nilai Variance Inflation Factor (VIF) tidak lebih dari 10, dan nilai Tolerance tidak kurang dari 0,1 maka model dapat 
Decy Wulan S., Ni Nyoman Yuliati, \& Rusli Amrul : Pengaruh Pengendalian Internal.....

dikatakan terbebas dari multikolinieritas. Nilai Tolerance (a) dapat dihitung dengan persamaan $(a=1 / \mathrm{VIF})$, sementara nilai Variance Inflation Factor dapat dihitung dengan persamaan (VIF $=1 / a)$. Variabel bebas mengalami multikolinieritas jika a hitung < a dan VIF hitung < VIF (Sunyoto, 2011:79).

\section{Uji Heterokedastisitas}

Uji heteroskedastisitas dilakukan untuk melihat sama atau tidak varians dari residual suatu observasi yang satu dengan observasi yang lain. Jika residualnya mempunyai varians yang sama, disebut terjadi homoskedastisitas, dan jika variansnya tidak sama terjadi heteroskedastisitas, serta yang diharapkan terjadi adalah homoskedastisitas. Uji heteroskedastisitas dilakukan untuk melihat sama atau tidak varians dari residual dari observasi yang satu dengan observasi yang lain. Jika residualnya mempunyai varians yang sama, disebut terjadi homoskedastisitas, dan jika variansnya tidak sama terjadi heteroskedastisitas.

Dengan uji Glejser, heteroskedastisitas terjadi jika nilai signifikansi antara variabel independen dengan absolut residual lebih dari kecil 0,05. Sementara homoskedastisitas terjadi jika nilai signifikansi lebih besar dari 0,05.

\section{Analisis Regresi Linear Berganda}

Dalam penelitian ini analisis yang digunakan yaitu analisis regresi linier berganda. Analisis regresi linier berganda digunakan untuk mengukur hubungan atau tingkat asosiasi antara variabel-variabel bebas terhadap variabel terikat secara simultan. Secara umum persamaan regresi linier berganda pada penelitian ini dinyatakan dengan rumus:

\begin{tabular}{lll|} 
& $\mathbf{Y =} \mathbf{a}+\mathbf{b}_{\mathbf{1}} \mathbf{X}_{\mathbf{1}}+\mathbf{b}_{\mathbf{2}} \mathbf{X}_{\mathbf{2}} \mathbf{e}$ \\
$\mathrm{Y}$ & $=$ & Kecurangan akuntansi SKPD Kota Mataram \\
$\mathrm{X}_{1}=$ & Pengendalian Internal \\
$\mathrm{X}_{2}=$ & Pengendalian Integritas \\
$\mathrm{a}$ & $=$ & Konstanta \\
$\mathrm{b}_{1}=$ & Koefisien regresi pengendalian internal \\
$\mathrm{b}_{2}=$ & Koefisien regresi pengendalian integritas \\
$\mathrm{e}$ & $=$ & Residual error
\end{tabular}

\section{Pengujian Hipotesis}

1) Pengujian Parsial (Uji t)

Statistik uji t digunakan untuk menguji secara sendiri-sendiri hubungan antara variabel bebas (Variabel X) dan variabel terikat (Variabel Y) (Sugiyono, 
2009:235).

Untuk mencari t tabel dengan $\mathrm{df}=\mathrm{N}-2$, taraf nyata $5 \%(=0,05)$ dapat dilihat dengan menggunakan tabel statistik. Nilai $t$ tabel dapat dilihat dengan menggunakan tabel t. Dasar pengambilan keputusan adalah:

a) Jika $t$ hitung $>t$ tabel, maka $\mathrm{Ha}$ diterima dan $\mathrm{H}_{0}$ ditolak.

b) Jika $t$ hitung $<t$ tabel, maka $\mathrm{Ha}$ ditolak dan $\mathrm{H}_{0}$ diterima.

Keputusan statistik hitung dan statistik tabel dapat juga dilakukan berdasarkan probabilitas, dengan dasar pengambilan keputusan sebagai berikut:

a) Jika probabilitas < tingkat signifikan, maka $\mathrm{Ha}$ diterima dan $\mathrm{H}_{0}$ ditolak.

b) Jika probabilitas > tingkat signifikan, maka $\mathrm{Ha}$ ditolak dan $\mathrm{H}_{0}$ diterima.

2) Pengujian Simultan (Uji F)

Pengujian ini melibatkan kedua variabel bebas (pengendalian internal dan integritas) terhadap variabel terikat (kecenderungan kecurangan) dalam menguji ada tidaknya pengaruh secara bersama-sama. Pengujian secara simultan menggunakan distribusi $F$, yaitu membandingkan antara $F$ hitung dan $\mathrm{F}$ tabel.

3) Koefesien Determinasi $\left(R^{2}\right)$

Koefesian determinasi pada regresi linier sering diartikan sebagai seberapa besar kemampuan semua variabel bebas dalam menjelaskan varians dan variabel terikatnya. Uji $\mathrm{R}^{2}$ atau uji determinasi merupakan satuan ukuran yang penting dalam regresi, karena dapat menginformasikan baik atau tidaknya model regresi yang terestimasi, atau dengan kata lain angka tersebut dapat mengukur seberapa dekatkah garis regresi yang terestimasi dengan data yang sesungguhnya. Nilai koefisien determinasi $\left(R^{2}\right)$ ini mencerminkan seberapa besar variasi dan variabel terikat $Y$ dapat diterangkan oleh $X$ sama sekali. Sementara bila $R^{2}=1$, artinya variasi dari $Y$ secara keseluruhan dapat diterangkan oleh variabel $X$.

\section{PEMBAHASAN}

Deskripsi Variabel Penelitian

1. Karakteristik Responden Berdasarkan Gender Tabel 4.1. Data Responden Berdasarkan Gender

\begin{tabular}{|l|l|c|c|}
\hline No & Jenis Kelamin & Jumlah & $(\%)$ \\
\hline 1 & Laki - Laki & 43 & 72 \\
\hline 2 & Perempuan & 17 & 28 \\
\hline & Jumlah & 60 & 100 \\
\hline
\end{tabular}


Decy Wulan S., Ni Nyoman Yuliati, \& Rusli Amrul : Pengaruh Pengendalian Internal.....

Sumber: Data Primer Diolah

Jenis kelamin responden dapat digunakan sebagai acuan untuk mengetahui keterlibatan gender dalam kecenderungan kecurangan akuntansi. Dari hasil tabulasi data responden,terlihat bahwa responden laki-laki sebanyak 43 orang (72 persen) dan perempuan sebanyak 17 orang ( 28 persen).

\section{Karakteristik Responden Berdasarkan Usia}

Tabel 4.2. Data Responden Berdasarkan Usia

\begin{tabular}{|l|l|c|c|}
\hline No & Lama Bekerja & Jumlah & $(\%)$ \\
\hline 1 & $\leq 30$ Tahun & 20 & 33 \\
\hline 2 & $31-40$ Tahun & 23 & 38 \\
\hline 3 & $41-50$ Tahun & 9 & 15 \\
\hline 4 & $\geq 51$ Tahun & 8 & 14 \\
\hline & Jumlah & 60 & 100 \\
\hline
\end{tabular}

Sumber: Data Primer Diolah

Dari data table 4.2. terlihat bahwa responden yang mendominasi adalah dengan rentang usia 31 - 40 tahun, yaitu sebanyak 23 orang (38 persen) dan yang terendah adalah responden dengan rentang usia $\geq 51$ tahun yaitu sebanyak 8 orang (14 persen). Hal ini menunjukkan bahwa responden dalam penelitian ini memiliki umur yang cukup matang dari sisi usia, dan telah mempunyai pengalaman yang cukup dalam menjalankan pekerjaan dan mengemban jabatan.

\section{Karakteristik Responden Berdasarkan Lama Bekerja} Tabel 4.3. Data Responden Berdasarkan Lama Berkerja

\begin{tabular}{|l|l|c|c|}
\hline No & Lama Bekerja & Jumlah & $(\%)$ \\
\hline 1 & $<5$ Tahun & 12 & 20 \\
\hline 2 & $5-10$ Tahun & 30 & 50 \\
\hline 3 & $>10$ Tahun & 18 & 30 \\
\hline & Jumlah & 60 & 100 \\
\hline
\end{tabular}

Sumber: Data Primer Diolah

Berdasarkan tabel diatas, responden yang mendominasi adalah dengan rentang lama bekerja 5 - 10 Tahun yaitu sebanyak 30 orang (50 persen) dan yang terendah adalah responden dengan rentang lama bekerja $<5$ tahun yaitu sebanyak 12 orang (20 persen). Hal ini menunjukkan responden yang terpilih mayoritas telah mempunyai wawasan dan pengalaman dalam penyusunan anggaran dan pengelolaan keuangan pada Dinas SKPD Kota Mataram. 


\section{Karakteristik Responden Berdasarkan Tingkat Pendidikan}

Tabel 4.4. Data Responden Berdasarkan Tingkat Pendidikan

\begin{tabular}{|l|l|c|c|}
\hline No & Pendidikan & Jumlah & $(\%)$ \\
\hline 1 & SMA & 5 & 8 \\
\hline 2 & D3 & 11 & 18 \\
\hline 3 & Strata I (S1) & 37 & 62 \\
\hline 4 & Strata II (S2) & 7 & 12 \\
\hline & Jumlah & 60 & 100 \\
\hline
\end{tabular}

Sumber: Data Primer Diolah

Pada Tabel 4.4 dapat dilihat bahwa sebagian besar responden berlatar belakang pendidikan S1 sebanyak 37 orang (62 persen) dan responden berlatar belakang pendidikan SMA sebanyak 5 orang (8 persen). Umumnya aparatur dengan tingkat pendidikan tinggi mampu untuk lebih memahami tugas dan fungsinya serta mempelajari dan memahami peraturan-peraturan yang diperlukan dalam menjalankan tugasnya.

\section{Uji Normalitas}

Uji normalitas dengan statistik menggunakan uji Kolmogorov-Smirnov sebagaimana telah diuraikan pada Prosedur Analisis Data dalam BAB III. Hasil output SPSS-nya adalah sebagai berikut:

Tabel 4.10. Uji Normalitas Data

\begin{tabular}{|c|c|c|}
\hline & & $\begin{array}{l}\text { Unstandardized } \\
\text { Residual }\end{array}$ \\
\hline$N$ & & 60 \\
\hline & Mean & 0,0000000 \\
\hline Normal Parameters ${ }^{a, b}$ & \begin{tabular}{|l|} 
Std. \\
Deviation
\end{tabular} & 0,52876230 \\
\hline & Absolute & 0,146 \\
\hline $\begin{array}{l}\text { MOSt } \\
\text { Differencec }\end{array}$ & Positive & 0,146 \\
\hline & Negative & $-0,080$ \\
\hline Kolmogorov-Smirnov Z & & 0,146 \\
\hline Asymp. Sig. (2-tailed) & & 0,292 \\
\hline
\end{tabular}

Berdasarkan Tabel 4.10 dapat dikatakan bahwa residual dari fungsi pengaruh variabel pengendalian internal dan integritas terhadap kecenderungan kecurangan akuntansi pada Dinas SKPD Kota Mataram telah terdistribusi secara normal. Hal ini ditunjukkan oleh nilai Asymp. Sig. (2-tailed) pada uji Kolmogorov-Smirnov sebesar 0,292 dimana nilai ini lebih besar dari syarat yang telah ditentukan sebesar 0,050. 
Decy Wulan S., Ni Nyoman Yuliati, E Rusli Amrul : Pengaruh Pengendalian Internal.....

\section{Uji Multikolinieritas}

Untuk mendeteksi gejala multikolinieritasdilakukan dengan cara melihat nilai Variance Inflation Factor (VIF) dan Tolerance pada Tabel 4.11 berikut ini:

Tabel 4.11. Besaran Nilai VIF dan Tolarance

\begin{tabular}{|c|c|c|}
\hline \multirow{2}{*}{ Model } & \multicolumn{2}{|c|}{ Collinearity Statistics } \\
\cline { 2 - 3 } & Tolerance & VIF \\
\hline $\begin{array}{c}\text { Pengendalian Internal } \\
(\mathrm{X} 1)\end{array}$ & 0,571 & 1,752 \\
\hline $\begin{array}{c}\text { Integritas } \\
(\mathrm{X} 2)\end{array}$ & 0,571 & 1,752 \\
\hline
\end{tabular}

Pada hasil perhitungan uji multikolinieritas sebagaimana terlihatdalam Tabel 4.11, tidak ada satupun variabel independen (pengendalian internal dan integritas) yang memiliki nilai VIF lebih dari 10 (VIF < 10) dan nilai tolerance lebih kecil dari 0,100. Dengan demikian dapat disimpulkan bahwa tidak ada multikolinieritas antar variabel bebas yang digunakan dalam penelitian ini.

\section{Uji Heteroskedastisitas}

Asumsi penting dalam regresi linier adalah bahwa gangguan yang muncul dalam model regresi korelasi adalah homoskedastisitas yaitu semua gangguan mempunyai variasi yang sama. Dalam regresi mungkin ditemui gejala heteroskedastisitas. Pengujian heteroskedastisitas dengan metode statistik menggunakan uji Glejser. Hasil analisis terhadap heteroskedastisitas dapat dilihat pada Tabel 4.12 berikut:

Tabel 4.12. Hasil Uji Heteroskedastisitas

\begin{tabular}{|l|c|c|c|}
\hline \multicolumn{1}{|c|}{ Variabel } & $\begin{array}{c}\text { Nilai } \\
\text { t Hitung }\end{array}$ & $\begin{array}{c}\text { Nilai } \\
\text { Signifikansi }\end{array}$ & Keterangan \\
\hline $\begin{array}{l}\text { Pengendalian } \\
\text { Internal } \\
(X 1)\end{array}$ & 1,149 & 0,255 & Homoskedastis \\
\hline $\begin{array}{l}\text { Integritas } \\
(X 2)\end{array}$ & $-1,939$ & 0,057 & Homoskedastis \\
\hline
\end{tabular}

Hasil uji heteroskedastisitas pada Tabel 4.12 menunjukkan bahwa tidak ada variabel independen yang signifikan secara statistik mempengaruhi nilai absolut residual variabel dependen. Hal ini terlihat dari probabilitas signifikansinya di atas tingkat kepercayaan 5 persen. Maka dapat dikatakan tidak terjadi heteroskedastisitas pada data penelitian mengenai pengaruh variabel 
pengendalian internal dan integritas terhadap kecenderungan kecurangan akuntansi pada Dinas SKPD Kota Mataram.

\section{Uji Validitas}

Tabel 4.8. Uji Validitas dari Masing-masing Indikator

\begin{tabular}{|c|c|c|c|c|c|}
\hline No & Variabel & Item & $\begin{array}{l}\text { Nilai } \\
\text { rhitung }\end{array}$ & $\begin{array}{l}\text { Nilai } \\
\text { r }_{\text {kritis }}\end{array}$ & Ket \\
\hline 1 & \multirow{9}{*}{$\begin{array}{l}\text { Pengendalian } \\
\text { Internal } \\
\left(X_{1}\right)\end{array}$} & $X_{1.1}$ & 0,717 & \multirow{9}{*}{0,300} & Valid \\
\hline 2 & & $X_{1.2}$ & 0,798 & & Valid \\
\hline 3 & & $X_{1.3}$ & 0,717 & & Valid \\
\hline 4 & & $X_{1.4}$ & 0,798 & & Valid \\
\hline 5 & & $X_{1.5}$ & 0,690 & & Valid \\
\hline 6 & & $X_{1.6}$ & 0,798 & & Valid \\
\hline 7 & & $X_{1.7}$ & 0,717 & & Valid \\
\hline 8 & & $X_{1.8}$ & 0,798 & & Valid \\
\hline 9 & & $\mathrm{X}_{1.9}$ & 0,690 & & Valid \\
\hline 10 & \multirow{14}{*}{$\begin{array}{l}\text { Integritas } \\
\left(X_{2}\right)\end{array}$} & $X_{2.1}$ & 0,728 & \multirow{14}{*}{0,300} & Valid \\
\hline 11 & & $X_{2.2}$ & 0,540 & & Valid \\
\hline 12 & & $X_{2.3}$ & 0,654 & & Valid \\
\hline 13 & & $X_{2.4}$ & 0,728 & & Valid \\
\hline 14 & & $X_{2.5}$ & 0,540 & & Valid \\
\hline 15 & & $X_{2.6}$ & 0,728 & & Valid \\
\hline 16 & & $X_{2.7}$ & 0,540 & & Valid \\
\hline 17 & & $X_{2.8}$ & 0,654 & & Valid \\
\hline 18 & & $X_{2.9}$ & 0,728 & & Valid \\
\hline 19 & & $X_{2.10}$ & 0,540 & & Valid \\
\hline 20 & & $X_{2.11}$ & 0,693 & & Valid \\
\hline 21 & & $X_{2.12}$ & 0,654 & & Valid \\
\hline 22 & & $X_{2.13}$ & 0,728 & & Valid \\
\hline 23 & & $X_{2.14}$ & 0,728 & & Valid \\
\hline 24 & \multirow{10}{*}{$\begin{array}{l}\text { Kecenderungan } \\
\text { Kecurangan } \\
\text { Akuntansi } \\
(\mathrm{Y})\end{array}$} & $Y_{1.1}$ & 0,566 & \multirow{10}{*}{0,300} & Valid \\
\hline 25 & & $Y_{1.2}$ & 0,383 & & Valid \\
\hline 26 & & $Y_{1.3}$ & 0,700 & & Valid \\
\hline 27 & & $Y_{1.4}$ & 0,607 & & Valid \\
\hline 28 & & $Y_{1.5}$ & 0,700 & & Valid \\
\hline 29 & & $Y_{1.6}$ & 0,607 & & Valid \\
\hline 30 & & $Y_{1.7}$ & 0,700 & & Valid \\
\hline 31 & & $Y_{1.8}$ & 0,607 & & Valid \\
\hline 32 & & $Y_{1.9}$ & 0,566 & & Valid \\
\hline 33 & & $Y_{1.10}$ & 0,383 & & Valid \\
\hline
\end{tabular}


Decy Wulan S., Ni Nyoman Yuliati, E Rusli Amrul : Pengaruh Pengendalian Internal.....

\begin{tabular}{|c|c|c|c|}
\hline 34 & $Y_{1.11}$ & 0,700 & Valid \\
\hline 35 & $Y_{1.12}$ & 0,607 & Valid \\
\hline 36 & $Y_{1.13}$ & 0,700 & Valid \\
\hline 37 & $Y_{1.14}$ & 0,607 & Valid \\
\hline
\end{tabular}

Dari Tabel 4.8 terlihat bahwa nilai $r$ dari semua indikator lebih besar dari nilai $r$ kritisyaitu 0,300 sehingga dapat ditarik kesimpulan bahwa instrumen penelitian terkait pengendalian internal, integritas, dan kecenderungan kecurangan akuntansi pada Dinas SKPD Kota Mataram tergolong valid sehingga data yang dikumpulkan dapat dianalisis lebih lanjut.

Uji Reliabilitas

Tabel 4.9. Uji Reliabilitas Masing-masing Variabel

\begin{tabular}{|c|c|c|c|}
\hline No & Variabel & $\begin{array}{l}\text { Cronbach's } \\
\text { Alpha }\end{array}$ & Keterangan \\
\hline 1 & $\begin{array}{c}\text { Pengendalian Internal } \\
(\mathrm{X} 1)\end{array}$ & 0,777 & Reliabel \\
\hline 2 & $\begin{array}{c}\text { Integritas } \\
(\mathrm{X} 2)\end{array}$ & 0,759 & Reliabel \\
\hline 3 & $\begin{array}{c}\text { Kecenderungan Kecurangan } \\
\text { Akuntansi (Y) }\end{array}$ & 0,750 & Reliabel \\
\hline
\end{tabular}

Dari Tabel 4.9 dapat dilihat bahwa nilai Cronbach Alphalebih besar dari 0,600 sehingga dapat ditarik kesimpulan bahwa variabel pengendalian internal, integritas, dan kecenderungan kecurangan akuntansi pada Dinas SKPD Kota Mataram yang digunakan dalam penelitian ini dikatakan reliabel.

\section{Analisis Regresi Linier Berganda}

Analisis regresi linier berganda dilakukan dalam rangka uji model untuk mengetahui apakah variabel pengendalian internal $\left(X_{1}\right)$ dan integritas $\left(X_{2}\right)$ mempunyai pengaruh yang signifikan secara parsial dan simultan terhadap kecenderungan kecurangan akuntansi $(\mathrm{Y})$ pada Dinas SKPD Kota Mataram. Hasil perhitungan regresi linier berganda disajikan sebagai berikut:

Tabel 4.13. Uji Model Pengaruh Pengendalian Internal dan Integritas terhadap Kecenderungan Kecurangan Akuntansi pada Dinas SKPD Kota Mataram

\begin{tabular}{|c|c|c|c|c|c|c|}
\hline \multirow[t]{2}{*}{ Model } & & \multicolumn{2}{|c|}{$\begin{array}{l}\text { Unstandardized } \\
\text { Coefficients }\end{array}$} & \multirow{2}{*}{\begin{tabular}{|l|}
$\begin{array}{l}\text { Standardized } \\
\text { Coefficients }\end{array}$ \\
Beta
\end{tabular}} & \multirow{2}{*}{$t$} & \multirow[t]{2}{*}{ Sig. } \\
\hline & & $B$ & Std. Error & & & \\
\hline & (Constant) & 4,489 & 0,430 & & 10,435 & 0,000 \\
\hline & $\mathrm{X} 1$ & $-0,260$ & 0,103 & $-0,345$ & $-2,518$ & 0,015 \\
\hline & $\mathrm{X} 2$ & $-0,445$ & 0,179 & $-0,340$ & $-2,484$ & 0,016 \\
\hline
\end{tabular}


Sumber: Lampiran 7

Berdasarkan tabel diatas maka persamaan regresi linier berganda sebagai berikut:

$$
\begin{gathered}
Y=b_{0}+b_{1} X_{1}+b_{2} X_{2}+e \\
Y=4,489-0,260 X_{1}-0,445 X_{2}+e
\end{gathered}
$$

Adapun penjelasan persamaan di atas, dapat dijabarkan bahwa koefisien konstanta sebesar 4,489menunjukkan bahwa jika variabel pengendalian internal $\left(X_{1}\right)$ dan integritas $\left(X_{2}\right)$ dianggap konstan, maka kecenderungan kecurangan akuntansi pada Dinas SKPD Kota Mataram (Y) akan mengalami peningkatan sebesar 4,489. Selanjutnya akan diuraikan mengenai koefisien regresi dari masing-masing variabel penelitian, berikut uraiannya:

a) Pengendalian Internal

Nilai koefisien regresi variabel pengendalian internal $\left(X_{1}\right)$, adalah sebesar 0,260. Artinya jika pengendalian internalditingkatkan100 persen, maka kecenderungan kecurangan akuntansi pada Dinas SKPD Kota Mataram (Y) akan mengalami penurunan sebesar 26 persen dengan asumsi variabel integritas tetap.Koefisien regresi yang bertanda negatif menunjukkan pengaruh yang berlawanan arah antara pengendalian internal dengan kecenderungan kecurangan akuntansi.

b) Integritas

Nilai koefisien regresi variabel integritas $\left(X_{2}\right)$, adalah sebesar $-0,445$. Artinya jika integritaspegawai ditingkatkan 100 persen, maka kecenderungan kecurangan akuntansi pada Dinas SKPD Kota Mataram (Y) akan mengalami penurunan sebesar 44,50 persen dengan asumsi variabel pengendalian internal tetap. Koefisien regresi yang bertanda negatif menunjukkan pengaruh yang berlawanan arah antara integritas pegawai dengan kecenderungan kecurangan akuntansi.

\section{Pengujian Hipotesis} Uji Parsial

Tabel 4.15. Hasil Uji Parsial

\begin{tabular}{|c|c|c|c|c|}
\hline Variabel & $\begin{array}{c}\text { Nilai } \\
\text { t Hitung }\end{array}$ & $\begin{array}{c}\text { Nilai } \\
\text { Signifikansi }\end{array}$ & $\begin{array}{c}\text { Nilai } \\
\text { t Tabel }\end{array}$ & Keterangan \\
\hline $\begin{array}{c}\text { Pengendalian internal } \\
(\mathrm{X} 1)\end{array}$ & $-2,518$ & 0,015 & $-2,000$ & Signifikan \\
\hline $\begin{array}{c}\text { Integritas } \\
(\mathrm{X} 2)\end{array}$ & $-2,484$ & 0,016 & $-2,000$ & Signifikan \\
\hline
\end{tabular}

Sumber : Lampiran 7 
Decy Wulan S., Ni Nyoman Yuliati, E Rusli Amrul : Pengaruh Pengendalian Internal.....

Secara parsial, variabel pengendalian internal mempunyai pengaruh yang signifikan terhadap kecenderungan kecurangan akuntansi pada Dinas SKPD Kota Mataram. Hal ini ditunjukkan oleh nilai -t hitung sebesar 2,518 yang lebih kecil dari nilai $-\mathrm{t}$ tabel sebesar $-2,000$. Berdasarkan nilai signifikansi juga dapat dibuktikan dengan nilai sig yang diperoleh sebesar 0,015 , dimana nilai ini lebih kecil dari syarat ketentuan nilai signifikansi sebesar 0,050. Dengan demikian hipotesis pertama yang diajukan dalam penelitian ini dinyatakan dapat diterima.

Secara parsial variabel integritas pegawai mempunyai pengaruh yang signifikanterhadap kecenderungan kecurangan akuntansi pada Dinas SKPD Kota Mataram, ditunjukkan dengan nilai $-\mathrm{t}$ hitung sebesar $-2,484$ yang lebih kecildari nilai $-\mathrm{t}$ tabel sebesar $-2,000$. Selain itu juga dapat dilihat dari nilai signifikansi yang diperoleh variabel integritas pegawai sebesar 0,016yang masih berada di bawah nilai ketentuan signifikan sebesar 0,050. Ini menyatakan menolak $\mathrm{H}_{0}$ dan menerima $\mathrm{H}_{\mathrm{a}}$, atau dengan kata lain hipotesis kedua yang diajukan dalam penelitian ini terbukti atau dapat diterima.

\section{Uji Simultan}

Tabel 4.16. Hasil Analysis of Variance (ANOVA)

\begin{tabular}{|c|l|c|c|c|c|c|}
\hline \multicolumn{2}{|c|}{ Model } & $\begin{array}{c}\text { Sum of } \\
\text { Squares }\end{array}$ & $D f$ & Mean Square & $F$ & Sig. \\
\hline \multirow{3}{*}{1} & Regression & 10,502 & 2 & 5,251 & 18,145 & 0,000 \\
\cline { 2 - 7 } & Residual & 16,496 & 57 & 0,289 & & \\
\cline { 2 - 7 } & Total & 26,998 & 59 & & & \\
\hline
\end{tabular}

Sumber: Lampiran 7

Pada tingkat kepercayaan 95 persen ( $\alpha=5$ persen) diperoleh nilai $F$ tabel sebesar 3,160 sedangkan nilai $F_{\text {hitung }}$ sebesar 18,145 . Dengan demikian nilai $\mathrm{F}$ hitunglebih besar dari $\mathrm{F}$ tabel dan nilai signifikansi sebesar 0,000 yang lebih kecil dari syarat ketentuan signifikan sebesar 0,050. Ini berarti bahwa variabel pengendalian internaldan integritas pegawaiberpengaruh signifikan secara simultan terhadap kecenderungan kecurangan akuntansi pada Dinas SKPD Kota Mataram. Hal ini membuktikan bahwa hipotesis ketiga yang diajukan dalam penelitian ini terbukti atau dapat diterima.

\section{Koefisien Determinasi ( $R$ )}

Tabel 4.14. Hasil Model Summary

\begin{tabular}{|c|c|c|c|c|}
\hline Model & $R$ & $R$ Square & $\begin{array}{c}\text { Adjusted } R \\
\text { Square }\end{array}$ & $\begin{array}{c}\text { Std. Error of } \\
\text { the Estimate }\end{array}$ \\
\hline 1 & 0,624 & 0,389 & 0,368 & 0,53796 \\
\hline
\end{tabular}


Sumber: Lampiran 7

Besarnya nilai Adjusted $R$ Square pada Tabel Model Summarydi atas adalah 0,368. Hal ini berarti 36,80 persen variabel kecenderungan kecurangan akuntansi pada Dinas SKPD Kota Mataram dapat dijelaskan oleh kedua variabel bebas dalampenelitianini, yaitu variabel pengendalian internal dan integritas. Sedangkan sisanya sebesar 63,20 persen dijelaskan oleh variabel-variabel yang lain di luar model penelitian

\section{KESIMPULAN DAN SARAN}

\section{Kesimpulan}

Berdasarkan hasil analisis data dan pembahasan yang telah diuraikan sebelumnya, maka dapat dikemukakan beberapa kesimpulan sebagai berikut:

1) Variabel pengendalian internal secara parsial berpengaruh signifikan terhadapkecenderungan kecurangan akuntansi pada Dinas SKPD Kota Mataram. Ini berarti semakin efektif pengendalian internal maka semakin rendah kecenderungan kecurangan akuntansi dalam pengelolaan keuangan suatu organisasi. Dengan kata lain semakin tinggi pengendalian internal dapat menurunkan kecenderungan kecurangan akuntansi, sebaliknya jika semakin rendah pengendalian internal terkait dengan penganggaran, maka semakin meningkat pula kecenderungan terjadinya kecurangan akuntansi pada suatu organisasi atau instansi.

2) Variabel integritas pegawai secara parsial berpengaruh signifikan terhadapkecenderungan kecurangan akuntansi pada Dinas SKPD Kota Mataram, hal ini ditunjukkan oleh nilai signifikansi yang lebih kecil dari lima persen. Temuan ini menyatakan bahwa semakin berintegritas pegawai maka semakin rendah kecenderungan kecurangan akuntansi dalam pengelolaan keuangan organisasi. Dengan kata lain semakin tinggi integritas pegawai dapat menurunkan kecenderungan kecurangan akuntansi, sebaliknya jika semakin rendah integritas pegawai terkait dengan penganggaran, maka semakin meningkat pula kecenderungan terjadinya kecurangan akuntansi pada suatu organisasi atau instansi.

3) Variabel pengendalian internal dan integritas pegawai secara simultan berpengaruh signifikan terhadapkecenderungan kecurangan akuntansi pada Dinas SKPD Kota Mataram. Adanya pengaruh yang signifikan antara variabel tersebutjuga berarti bahwa dengan meningkatkan pengendalian internal dan integritas pegawai dalam suatu organisasi akan menjadi salah satu faktor penentu keberhasilan organisasi dari kecenderungan terjadinya kecurangan akuntansi. 
Decy Wulan S., Ni Nyoman Yuliati, \& Rusli Amrul : Pengaruh Pengendalian Internal.....

\section{Saran}

Dari hasil pembahasan analisis penelitian dan mempertimbangkan berbagai temuan dalam pengumpulan data, maka saran-saran yang perlu dikemukakan dalam penelitian ini adalah sebagai berikut:

1) Dalam rangka menekan kecenderungan kecurangan akuntansi pada Dinas SKPD Kota Mataram maka pimpinan harus menjaga pengendalian internal yang telah diimplementasikannya selama ini. Selain itu pimpinan harus meningkatkan terlebih dahulu integritas para pegawainya. Hal tersebut disebabkan karena pengendalian internal dan integritas pegawai sebagai satu kesatuan untuk menekan kecenderungan terjadinya kecurangan akuntansi.Setiap organisasi dalam lingkup Dinas SKPD Kota Mataram khususnya yang terkait dengan bidang keuangan, hendaknya melaksanakan evaluasi berkala mengenai pengendalian internal yang telah diimplementasikan. Organisasi juga harus melakukan bimbingan, pendidikan, serta pengembangan kemampuan seluruh pegawai terkait dengan konsep integritas pada Dinas SKPD Kota Mataram.

2) Integritas pegawai berpengaruh signifikan terhadap kecenderungan kecurangan akuntansi pada Dinas SKPD Kota Mataram. Berdasarkan kondisi ini maka pihak Dinas SKPD Kota Mataram agar dapat meningkatkan integritas pegawai yang terkait dengan pengelolaan keuangan, dapat dilakukan dengan pemberian insentif berupa penghargaan kepada setiap pegawai yang berprestasi memenuhi target organisasi dalam menekan tingkat kecenderungan kecurangan akuntansi.

\section{DAFTAR PUSTAKA}

Amin Widjadja Tunggal. 1992. Pemeriksaan Kecurangan (Fraud Auditing). Jakarta: PT. Rineka Cipta.

. 2010. Teori dan Praktek Auditing. Jakarta: Harvarindo

. 2013. Pokok Pokok Auditing dan Jasa Asuransi. Jakarta: Harvindo

Andi Amirullah Tiro Arif. 2014. Pengaruh Pengendalian Internal Dan Kompensasi Terhadap Kecenderungan Kecurangan (Fraud) Pada Pemerintah Kota Palopo. Universitas Hasanuddin Makassar. [Skripsi].

Ema Kurniawati. 2012. Analisis Faktor-Faktor yang Mempengaruhi Financial Statement Fraud dalam Perspektif Fraud Triangle. Unversitas Diponegoro. [Skripsi].

http://www.antikorupsi.org/id/.../bulletin-mingguan-anti-korupsi-14-18september-2015 (diakses tanggal 11 Maret 2017)

http://www.kpk.go.id/id/berita/siaran-pers/2332-kpk-umumkan-surveiintegritas-sektor-publik-2014 (diakses tanggal 10 Maret 2017). 
https://www.lomboktoday.co.id/2014/12/12/tiga-skpd-kota-mataram-terimapenghargaan-layanan-publik-1901.html (diakses tanggal 5 Mei 2017).

http://www.mataramkota.go.id/alamat-email-skpd.html (diakses tanggal 20 Maret 2017)

https://www.news.detik.com/berita/d-3405348/corruption-perceptions-index2016-indonesia-di-bawah-malaysia (diakses tanggal 7 mei 2017)

Ikatan Akuntan Indonesia. 2001. Standar Akuntansi Keuangan. Jakarta: IAI

Kadek Yuli Kurnia Dewi. 2016. Pengaruh Pengendalian Internal dan Integritas pada Kecenderungan Kecurangan Akuntansi (Studi pada SKPD Kota Denpasar). Universitas Udayana. [Skripsi].

Mulyadi. 2002. Auditing (Buku 1). Edisi 6. Jakarta : Salemba Empat.

. 2010. Sistem Akuntansi, Edisi 3, Cetakan ke-5. Jakarta: Salemba Empat.

PP Nomor 60. 2008. pasal 1 ayat 1 Pengendalian Internal.

Rachmat,Kriyantono. 2010. Teknik praktis riset. Jakarta : Kencana

Rifqi Mirza Zulkarnain. 2013. Analisis Faktor yang Mempengaruhi Terjadinya Fraud pada Dinas Kota Surakarta. Accounting Analysys Journal AAJ. 1(3): 25-47.

Ronald, j. Ellder \& Arens, Beasley Mark s .Alvin. 2008. Auditing dan jasa Assurance Pendekatan Terintegrasi. Jakarta: Erlangga.

Schlenker, B.R. 2008. Integrity and Character: Implications of Principled and Expedient ethical ideologis. Journal of Social and Clinical Psychology, 27(10), pp: 1078-1125.

STIE AMM Mataram. 2017. Buku Pedoman Skripsi

Sudjana. 2005. Metode Statistika. Bandung: Tarsito.

Sugiyono. 2009. Metode Penelitian Kuantitatif Kualitatif dan R\&D. Bandung: Alfabeta.

Sunyoto. 2011. Analisis regresi untuk uji hipotesis, Yogyakarta: Caps Vani Adelin. 2013. Pengaruh Pengendalian Internal, Ketaatan Aturan Akuntansi, dan Perilaku Tidak Etis Terhadap Kecenderungan Kecurangan Akuntansi (Studi Empiris pada BUMN di Kota Padang). Universitas Negeri Padang. [Skripsi].

Vani Adelin. 2013. Pengaruh Pengendalian Internal, Ketaatan Aturan Akuntansi, dan Perilaku Tidak Etis Terhadap Kecenderungan Kecurangan Akuntansi (Studi Empiris pada BUMN di Kota Padang). Universitas Negeri Padang. [Skripsi]. 